\title{
SCIDOC
}

International Journal of Dentistry and Oral Science (IJDOS)

ISSN: 2377-8075

\section{Novel Periodontal Pathogens In The Etiology Of Periodontitis}

Gayathri Varadharajulu ${ }^{1 *}$, Dhayanand John Victor ${ }^{2}$, Vasanthi $\mathrm{RM}^{3}$

${ }^{1}$ Post Graduate, Department of Periodontics, SRM Dental College and Hospital Chennai, India.

${ }^{2}$ Professor and Head of the department of Periodontics, SRM Dental College and Hospital Chennai, India.

${ }^{3}$ Post Graduate, Department of Periodontics, SRM Dental College and Hospital Chennai, India.

\section{Abstract}

Periodontitis is a predominantly polymicrobial and multifactorial chronic inflammatory disease of the periodontium. Though the role of host response is undebatable in the progress of the disease, the contribution of microbes is surmounting in initiating this complex disease. Over the years, with developments in science and technology, newer bacterial identification technologies incorporating open ended techniques have led to the discovery of various novel bacterial and archaeal species which have been associated with periodontal disease. This has been made possible by the latest $16 \mathrm{~S}$ rRNA sequencing and pyrosequencing that do not depend upon culture methods and thus point out even previously unknown bacteria implicated in periodontal disease. This descriptive review highlights the various novel bacteria and their characteristics, which are in recent times known to be associated with pathogenesis of periodontitis.

Keywords: Novel Periodontal Pathogens; Novel Periopathogens; Periodontitis; 16S rRNA Sequencing; Pyrosequencing; Next Generation Sequencing.

\section{Introduction}

Periodontitis is a multifactorial inflammatory oral disease characterised by progressive breakdown of the periodontium. The role of microbes in this complex disease may be directly harmful or indirect by means of altering the immuno-inflammatory mechanisms of the host. Therefore, the contribution of bacteria and their composition in the pathogenesis of periodontal inflammation has been studied for more than a century to decode its role in periodontal disease. In this quest, the major drawback with earlier techniques based on microbial cultures was that, only the species of microbiota already known to exist could be identified. Over the years, newer culture independent molecular methods such as those based on cloning and Sanger sequencing of the 16s rRNA have greatly expanded our knowledge of the microbial communities in the biofilm. [1] The emergence of advanced genomic technologies like the high throughput sequencing, also known as the deep sequencing of the 16s rRNA gene or the next generation sequencing was a pathbreaker in the improvement of sequencing technologies and has enormously contributed to the study of the microbiome. Park et al, 2015; Perez - Chaparo et al, 2014 [2, 3] these studies have shed light on several microbes other than the well-known red complex to be associated with periodontitis [4].

This observation is valid given that, the polymicrobial synergy and dysbiosis model of causation of periodontal disease suggests the alteration of host immune-inflammatory processes by a synergistic dysbiosis of a broad range of microbes rather than a single disease causing group [5].

This progress in knowledge as stated was mainly an outcome of the scientific and technological improvement in molecular methods, which allowed an open ended breakdown and understanding of the local microbiome facilitating the study of the uncultivated fraction of the microbiota. This literature review is an attempt to describe the range of oral microflora that could play a role in the disease process of periodontitis and have been associated with it at various levels. Table 1 lists the various novel periopathogens reviewed in this article.

\section{Cryptobacterium curtum}

The name Cryptobacterium curtum is derived from two Greek words "Kryptos" meaning to be hidden and "curtum" which

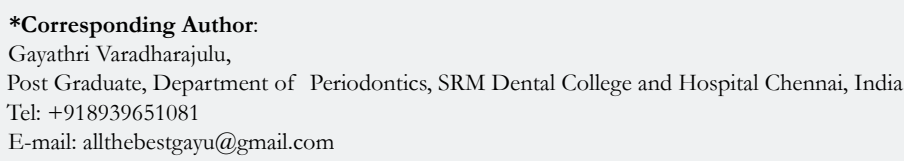

Copyright: Gayathri Varadharajulu 2021 . This is an open-access article distributed under the terms of the Creative Commons Attribution License, which permits unrestricted use, distribution and reproduction in any medium, provided the original author and source are credited. 
translates to shortened. Nakazawa et al, in 1999 isolated this species from the periodontal pocket of an adult patient with periodontitis [6]. C. curtum was also isolated from patients with necrotic dental pulps, root canals, dental abscess, and halitosis and was found associated with periodontal lesions. It was isolated from the periodontal pocket of an adult patient with periodontal disease. In the study by Kumar et al, in 2003 using 16 S ribosomal cloning and sequencing, this novel species was found to be associated strongly with periodontitis when stringent threshold of $\mathrm{p}<0.002$ was applied. This microbe was seen in high numbers in the periodontal microbiome of periodontally healthy individuals with rheumatoid arthritis $[7,8]$. Future studies are required to investigate the virulence properties, possible role and pathogenesis of this species in periodontal disease.

\section{Slackia exigua}

The name "slackia" was given to honour Geoffrey Slack - a distinguished microbiologist. "Exigua" in Latin means sparse referring to the scanty growth of this particular organism.Formerly, it was known as Eubacterium exiguum (1996) which was later reclassified by Wade as Slackia exigua in 1999 [9-11].

Smith and Wade et al in 1999 investigated the serum antibody response to E. brachy, E. nodatum, S. exigua, and M. timidum. S. exigua were seen to be present in higher levels in patients with chronic periodontitis as compared to healthy individuals and their levels were more in deep pockets as compared to shallow. Serum immunoglobulin A ( $\operatorname{Ig} \mathrm{A}$ ) levels against $\mathrm{M}$. timidum and S. exigua were also elevated in case of refractory periodontitis. This elevated systemic antibody response suggests that this asaccharolytic Eubacterium can sufficiently breach the host defense to stimulate an immune response. [12] S. exigua produces butyric acid from arginine which has a key role in promoting halitosis. Butyric acid also obstructs the proliferation of gingival fibroblasts and induces apoptosis in splenic $\mathrm{T}$ cells further leading to exacerbation of infectious lesions [13].

\section{Porphyromonas endodontalis}

Porphyromonas endodontalis is a black pigmented gram-negative microbe associated with periodontitis, endodontic infections, gingivitis and pulpal necrosis. Tran et al in 1997 were the first to report the detection of this species in periodontal pockets, though at a low concentration. It is suggested that P. endodontalis causes infection by releasing outer membrane blebs which may contain lipopolysaccharide [14]. Other possible virulence factors include capsule, proteases and toxins. Unlike the major periopathogen $P$. gingivalis, $P$. endodontalis does not produce trypsin-like enzymes and does not exhibit hemagglutination activity, nor has fimbriae. However, $P$. endodontalis has collagenases and proteases that can aid in the destruction of periodontium.

Several later studies showed high prevalence of $P$. endodontalis in diseased sites of patients with chronic periodontitis as compared to healthy sites. There was also significant correlation between $P$. endodontalis and two other putative periodontal pathogens $P$. gingivalis and T. forsythia suggesting that the presence of these three together can lead to changes in the subgingival environment thus influencing the development of periodontal disease $[6,15]$.

\section{Shuttleworthia satelles}

Shuttleworthia satelles was first isolated from the human periodontal pocket by Downes et al in 2002. This unusual novel pathogen was seen to be present in significantly elevated levels in refractory periodontitis as compared to good responders to periodontal therapy as well as periodontally healthy individuals [16]. Colombo et al, 2009 However, not much is known about the virulence characteristics or the extent of their involvement in periodontal disease [17].

\section{Eubacterium nodatum}

E. nodatum, Eubacteriumtimidum, and Eubacteriumbrachy, were first isolated, from subgingival plaque samples of patients with moderate and severe adult periodontitis. E. nodatum was seen in higher levels in subgingival plaque of periodontitis patients as compared to healthy controls [18, 19]. Booth et al, 2004.

Wade et al in 1996 found Eubacterium species to comprise $10.8 \%$ of the subgingivalmicrobiota in advanced periodontitis and have said to elaborate virulence factors such as esterases, acid phosphatases and aminopeptidases [20]. Uematsu and Hoshino et al in 1992 found this genus to make up 54 per cent of the anaerobic microbiota of periodontal pockets [21].

Eubacterium species saphenum was also seen to be present in significantly higher levels in periodontitis patients than in normal healthy individuals. Elevated levels of Eubacterium species in periodontal disease as compared to periodontal health was also seen in subsequent studies $[6,22]$.

\section{Filifactor alocis}

Filifactor alocis was first isolated in 1985 by Cato et al, from the gingivitis and periodontitis patients' gingival sulcus [23]. It is the third most prevalent pathogen in generalized aggressive periodontitis (45\%), second most prevalent in chronic periodontitis $(90 \%)$ but shows the least prevalence in periodontitis resistant groups [24].

The high prevalence of $F$. alocis in periodontitis could be attributed to its distinctive virulence properties such as oxidative stress resistance, proinflammatory cytokine production, involvement in periodontal biofilms that triggers host response by secretion of various proteases. F. alocis is detected at higher numbers in the middle third and apical region than in the cervical part of the pocket [25-27].

Protease (HMPREF038900122) in the extracellular fraction of F. alocis contains a collagenase peptidase function that could be implicated in tissue destruction in periodontal diseases.

F. alocis causes pro apoptotic cell death gingival epithelial cells and induces proinflammatory cytokine secretion by a transient activation of MEK $1 / 2$ and caspase- 3 that has impact on both intrinsic and extrinsic pathways. F. alocis modulates host response by coinfection of gingival epithelial cells, host cell signalling, metabolic host response, cell-cell interaction, and activation of oncogenes [28]. F. alocis also causes a significant dose-dependent MMP-1 upregulation in periodontitis. Further, F. alocis can manipulate the release of neutrophil extracellular traps (NETS) from neutrophils thus making its survival feasible even in host immune response 
Table 1. List of potential novel periopathogens elaborated in this descriptive review.

\begin{tabular}{|c|c|c|c|}
\hline ORGANISM & TAXONOMY & MORPHOLOGICAL FEATURES & CULTURE CHARACTERISTICS \\
\hline $\begin{array}{l}\text { Cryptobacterium } \\
\text { curtum }\end{array}$ & $\begin{array}{c}\text { Domain - Bacteria } \\
\text { Phylum - Actinobacteria } \\
\text { Class - Actinobacteria } \\
\text { Order - Coriobacteriales } \\
\text { Family - Coriobacteriaceae }\end{array}$ & $\begin{array}{l}\text { Gram-positive obligatory anaerobic } \\
\text { nonmotile nonsporing mesophilic asac- } \\
\text { charolytic rods } 0.8 \mu \mathrm{m} \text { to } 1.0 \mu \mathrm{m}, 10 \\
\text { nm thick single layer cell wall, without } \\
\text { Pili or flagella }\end{array}$ & $\begin{array}{l}\text { Miniscule translucent colonies of less than } 1 \\
\mathrm{~mm}(0.3-0.5 \mathrm{~mm}) \text { in diameter on BHI blood } \\
\text { agar without hemolysis }\end{array}$ \\
\hline Slackia exigua & $\begin{array}{c}\text { Domain - Bacteria } \\
\text { Phylum - Actinobacteria } \\
\text { Class - Actinobacteria } \\
\text { Order - Coriobacteriales } \\
\text { Family - Coriobacteriaceae } \\
\end{array}$ & $\begin{array}{l}\text { Gram-positive, nonsporing, nonmo- } \\
\text { tile, asaccharolytic, strictly anaerobic } \\
\text { bacillus, } 0.5 \mu \mathrm{m} \times 1.0 \mu \mathrm{m}\end{array}$ & $\begin{array}{l}\text { Colonies appear circular, convex, and trans- } \\
\text { lucent measuring }<1 \mathrm{~mm} \text { in diameter.Amino } \\
\text { acids are important metabolic substrates for } \\
\text { growth, particularly arginine and lysine }\end{array}$ \\
\hline $\begin{array}{l}\text { Porphyromonas } \\
\text { endodontalis }\end{array}$ & $\begin{array}{c}\text { Domain - Bacteria } \\
\text { Phylum - Bacteroidetes } \\
\text { Class - Bacteroidetes } \\
\text { Order - Bacteroidales Family - } \\
\text { Porphyromonadaceae } \\
\end{array}$ & $\begin{array}{l}\text { Gram negative, anaerobic, black pig- } \\
\text { mented, non-sporing, nonmotile rods }\end{array}$ & $\begin{array}{l}\text { Utilize nitrogenous substrates as energy sourc- } \\
\text { es, Pigment - protoheme, optimum growth - } \\
37 \text { C, slightly alkaline environments, produces } \\
\text { succinate }\end{array}$ \\
\hline $\begin{array}{l}\text { Shuttleworthia } \\
\text { satelles }\end{array}$ & $\begin{array}{c}\text { Domain - Bacteria } \\
\text { Phylum - Fermicutes } \\
\text { Class - Clostridia } \\
\text { Order - Clostridiales } \\
\text { Family - Lachnospiraceae } \\
\end{array}$ & $\begin{array}{l}\text { Gram-positive, non-sporing, obligately } \\
\text { anaerobic, non-motile bacilli, occurring } \\
\text { singly, in pairs, short chains and diphth- } \\
\text { eroid arrangements }\end{array}$ & $\begin{array}{l}\text { Saccharolytic, Acetate, butyrate and lactate } \\
\text { - end products of glucose fermentation. } \\
\text { Aesculin hydrolysed and indole produced. }\end{array}$ \\
\hline $\begin{array}{l}\text { Eubacterium } \\
\text { nodatum }\end{array}$ & $\begin{array}{l}\text { Kingdom - Bacteria } \\
\text { Phylum - Firmicutes } \\
\text { Class - Clostridia } \\
\text { Family - Clostridiales }\end{array}$ & $\begin{array}{l}\text { Gram-positive, non- sporing, non } \\
\text { motile,branched, filamentous rods, } \\
\text { obligate anaerobes }\end{array}$ & $\begin{array}{l}\text { Generally nonreactive, grow poorly and slowly, } \\
\text { bacteria clump together in broth cultures and } \\
\text { form biofilm, circular and raspberry-shaped } \\
\text { cream-colored colonies }\end{array}$ \\
\hline Filifactor alocis & $\begin{array}{c}\text { Domain - Bacteria } \\
\text { Phylum - Firmicutes } \\
\text { Class - Clostridia } \\
\text { Order - Clostridiales } \\
\text { Family - Peptostreptococcaceae }\end{array}$ & $\begin{array}{l}\text { Gram -positive, anaerobic rods, } 0.4 \\
\text { to } 0.7 \text { by } 1.5 \text { to } 7.0 \mathrm{pm} \text {, with rounded } \\
\text { to tapered ends,fastidious, possesses } \\
\text { trypsin-like enzymatic activity }\end{array}$ & $\begin{array}{l}\text { BHI broth supplemented with yeast extract } \\
(0.5 \mathrm{mg} / \mathrm{ml}), \mathrm{L} \text {-cysteine }(50 \mu \mathrm{g} / \mathrm{ml}) \text {, and } 20 \% \\
\text { arginine anaerobically at } 37^{\circ} \mathrm{C} \text { in } 10 \% \mathrm{H} 2, \\
10 \% \mathrm{CO} 2 \text {, and } 80 \% \mathrm{~N} 2 . \text { Arginine, lysine, and } \\
\text { cysteine stimulate the growth of } \mathrm{F} \text {. alocis in the } \\
\text { periodontal pocket environment. }\end{array}$ \\
\hline $\begin{array}{l}\text { Dialister pneu- } \\
\text { moscintes }\end{array}$ & $\begin{array}{c}\text { Domain - Bacteria } \\
\text { Phylum - Firmicutes } \\
\text { Class - Clostridia } \\
\text { Order - Clostridiales } \\
\text { Family - Veillonellaceae } \\
\end{array}$ & $\begin{array}{l}\text { Gram - negative nonmotile, nonspor- } \\
\text { ing, nonfermenting, small asaccharolyt- } \\
\text { ic, obligatory anaerobic microaerophilic } \\
\text { coccobacilli }\end{array}$ & $\begin{array}{l}\text { Small circular, tiny, smooth, and transparent } \\
\text { colonies on columbia blood agar. Grows in } \\
0.2 \% \text { hemolyzed sheep erythrocytes, } 0.0005 \% \\
\text { hemin, and } 0.00005 \% \text { menadione. Growth } \\
\text { most rapid in anaerobic environments at } 37^{\circ} \mathrm{C} \text {. }\end{array}$ \\
\hline $\begin{array}{l}\text { Anaeroglobus } \\
\text { geminatus }\end{array}$ & $\begin{array}{l}\text { Kingdom - bacteria } \\
\text { Phylum - Firmicutes } \\
\text { Class - Negativicutes } \\
\text { Family - Veillonellaceae } \\
\end{array}$ & $\begin{array}{l}\text { Gram-negative coccus, } \\
\text { Non sporing, anaerobic, non motile }\end{array}$ & $\begin{array}{l}\text { Mesophilic temperature, Columbia agar wirh } \\
10 \% \text { horse blood }\end{array}$ \\
\hline $\begin{array}{l}\text { Mitsuokella } \\
\text { dentalis }\end{array}$ & $\begin{array}{c}\text { Domain - Bacteria } \\
\text { Phylum - Firmicutes } \\
\text { Class - Clostridia } \\
\text { Order - Clostridiales } \\
\text { Family - Veillonellaceae } \\
\end{array}$ & $\begin{array}{c}\text { Gram - negative rods } \\
\text { nonmotile, nonsporing, } \\
\text { anaerobic } \\
0.7 \mu \mathrm{m} \text { by } 2 \mu \mathrm{m}\end{array}$ & $\begin{array}{l}\text { On enriched horse blood agar after } 3 \text { days of } \\
\text { incubation, it forms convex, irregular, translu- } \\
\text { cent, wet, and mucoid colonies of } 1-2 \mathrm{~mm} \text { in } \\
\text { diameter, with a water drop appearance. }\end{array}$ \\
\hline $\begin{array}{l}\text { Selenomonas } \\
\text { sputigena }\end{array}$ & $\begin{array}{l}\text { Domain - Bacteria } \\
\text { Phylum - Firmicutes } \\
\text { Class - Clostridia } \\
\text { Order - Clostridiales } \\
\text { Family - Veillonellaceae }\end{array}$ & $\begin{array}{c}\text { Gram-negative } \\
\text { flagellated, motile, anaerobic, cres- } \\
\text { cent-shaped }\end{array}$ & $\begin{array}{l}\text { Mac conkey plates, chocolate agar, brain heat } \\
\text { infusion agar supplemented with } 5 \% \text { sheep } \\
\text { blood, hemin, menadione, anaerobically at } \\
35^{\circ} \mathrm{C} \text { after } 4 \text { days. Small }(<0.5 \mathrm{~mm}) \text { grey white } \\
\text { opaque colonies. }\end{array}$ \\
\hline $\begin{array}{l}\text { Treponema leci- } \\
\text { thinolyticum }\end{array}$ & $\begin{array}{c}\text { Domain - Bacteria } \\
\text { Phylum - Spirochaetes } \\
\text { Class - Spirochaetes } \\
\text { Order - Spirochetales } \\
\text { Family - Spirochetaceae } \\
\end{array}$ & $\begin{array}{c}\text { Gram }- \text { negative } \\
\text { Facultative anaerobe } \\
\text { helically coiled, motile, } 5 \mu \mathrm{m} \times 0.15 \mu \mathrm{m} \\
\text { wide containing two endoflagella }\end{array}$ & $\begin{array}{l}\text { White diffuse subsurface colonies up to } 3 \mathrm{~mm} \\
\text { in diameter within } 7 \text { days of incubation at } \\
37^{\circ} \mathrm{C} \text {. (91) }\end{array}$ \\
\hline Synergistetes & $\begin{array}{c}\text { Domain - Bacteria } \\
\text { Phylum - Synergistetes, Class - } \\
\text { Synergistia } \\
\text { Order - Synergistales } \\
\text { Family - Synergistaceae } \\
\end{array}$ & $\begin{array}{l}\text { Gram-negative Fastidious, slow grow- } \\
\text { ing, obligate anaerobic nonmotile, non } \\
\text { pigmenting, nonsporing curved bacilli } \\
(0.7-0.8 \mu \mathrm{m} \text { wide, } 0.8-2.2 \mu \mathrm{m} \text { long }) \\
\text { arranged in pairs or short chains. } \\
\end{array}$ & $\begin{array}{l}\text { Colonies grown on Fastidious Anaerobic Agar } \\
\text { were } 0.7-1.1 \mathrm{~mm} \text { in diameter, circular, convex } \\
\text { to pyramidal, shiny with consistent opacity, and } \\
\text { off white to watery steel grey in colour. }\end{array}$ \\
\hline $\begin{array}{l}\text { Desulfobulbus } \\
\text { oralis }\end{array}$ & $\begin{array}{c}\text { Domain - Bacteria } \\
\text { Phylum - Proteobacteria } \\
\text { Class - Deltaproteobacteria } \\
\text { Order - Desulfobacterales } \\
\text { Family - Desulfobulbaceae } \\
\end{array}$ & $\begin{array}{c}\text { Gram negative, nonmotile, nonsporing } \\
\text { rods, } 1 \text { to } 2 \mu \mathrm{m} \text { in length and } 0.3 \mu \mathrm{m} \text { in } \\
\text { diameter, presence of outer membrane } \\
\text { vesicles ( } 25 \text { to } 50 \mathrm{~nm} \text { in diameter) on } \\
\text { some cells } \\
\end{array}$ & $\begin{array}{c}\text { Anaerobic }-37^{\circ} \mathrm{C} \text { in a minimal defined liquid } \\
\text { medium with lactate as the sole carbon and } \\
\text { electron source and sulfate as the electron } \\
\text { acceptor, supplemented with } 5 \% \text { (vol/vol) F. } \\
\text { nucleatum CFS }\end{array}$ \\
\hline $\begin{array}{l}\text { Methanobrevi- } \\
\text { bacter oralis }\end{array}$ & $\begin{array}{l}\text { Domain - Archaea } \\
\text { Phylum - Euryarchaeota } \\
\text { Class - Methanobacteria } \\
\text { Order - Methanobacteriales } \\
\text { Family - Methanobacteriaceae }\end{array}$ & $\begin{array}{l}\text { Gram-positive, Coccobacillus, nonmo- } \\
\text { tile, methane producing }\end{array}$ & $\begin{array}{l}\text { Optimal pH 6.9-7.4, at } 36-38^{\circ} \mathrm{C} . \text { Fecal extract } \\
\text { required, and growth stimulated by volatile } \\
\text { fatty acid mixture. } \mathrm{H} 2 \text { and } \mathrm{CO} 2 \text { required for } \\
\text { growth. }\end{array}$ \\
\hline
\end{tabular}


with neutrophils $[29,30]$.

Adherence and invasion of $F$. alocis is accentuated by $P$. gingivalis. Coinfection between $F$. alocis and $P$. gingivalis exhibits filopodial projections on surface of host cells that mediated organisms' internalization [30]. It was observed that F. alocis is more resistant than Porphyromonas gingivalis to hydrogen peroxide-induced oxidative stress, effective arginine metabolism [31]. Therefore, this property of $F$. alocis favors its high existence in periodontal pockets $[25,28,31]$.

The invasion of epithelial cells by F. alocis examined by in situ hybridization revealed that, F. alocis and P. gingivalis coexist forming biofilm of a mixed species thus hinting at a symbiotic relationship between the two. The investigations on community interactions of F. alocis revealed its relationship with microbes of varying pathogenicity such as the Streptococcus gordonii,Fusobacterium nucleatum, P. gingivalis, and Aggregatibacter actinomycetemcomitans as a major member of anaerobic niche $[31,33]$.

\section{Dialister pneumosintes}

This novel pathogen was first described by Olitsky and Gates. Bacteroides or D. pneumosintes was first isolated in early 1900 s from the nasopharyngeal secretions of patients with influenza and sinusitis. Currently, this genus Dialister comprises of four species D. pneumosintes, Dialisterinvisus, Dialistermicroaerophilus, and Dialisterpropionifaciens [34, 35].

The involvement of $D$. pneumosintes in periodontal conditions was not recognized for a long time. Only in the recent past the importance of this organism as an important component of subgingival microbiota has been brought to limelight. With refinements in molecular microbiology especially $16 \mathrm{~S}$ ribosomal RNA (rRNA) polymerase chain reaction (PCR) identification method, Ghayoumi et al. determined the presence of $\mathrm{D}$. pneumosintes from periodontal pockets and implicated it as "candidate pathogen" [35].

It is said that the lipopolysaccharides present in these cells leads to release of proinflammatory cytokines, prostaglandins, matrix metalloproteinases (MMPs) that eventually lead to periodontal connective tissue destruction, and resorption of alveolar bone [36]. D. pneumosintes is reported to be significantly higher in prevalence among patients with refractory periodontitis, rapidly progressing periodontitis suggesting its role in disease pathogenesis [37].

Presence of this organism in $83 \%$ of patients with severe periodontitis and in $19 \%$ of patients with moderate periodontitis lead to the suggestion of the organism being considered as "suspected periodontal pathogens." Silva et al. in 2009 reported higher counts of this bacteria in subgingival plaque of chronic patients than aggressive periodontitis (AgP) patients. Kamma et al, in 2001 showed that subgingival co-infection of D. pneumosintes along with $\mathrm{P}$. gingivalis was more closely related to progressive periodontitis than any of the two species alone $[38,39]$. They found that this co infection almost always was associated with gingival bleeding upon probing [40].

Comparing subgingival biofilm and saliva samples from subjects with periodontitis and healthy patients, Ferraro et al, in 2007 found significant associations between the prevalence of $\mathrm{D}$. pneumosintes and pocket depth, attachment loss and bleeding on probing [41].

\section{Selenomonas sputigena}

Moore et al., in 1987 isolated 5 new Selenomonas species S. artemidis, Selenomonasfluggei, Selenomonasdiane, Selenomonasinfelix, Selenomonasnoxia. Although all Selenomonas species dominated disease sites, Selenomonas sputigena was most frequently detected.

S. sputigena was detected in periodontal pockets of patients with chronic periodontitis, aggressive periodontitis suggesting its role as a potential pathogen and diagnostic marker for active periodontal disease [42]. Lucas et al, 2012.It induces release of interleukin 6 (IL-6), IL- $1 \alpha$ in macrophages thereby provoking inflammation $[43,44]$. It was seen to contribute to the upregulation of bacterial chemotaxis, flagellar assembly and two component system proteins as well as production of LPS which is a major factor in the pathogenesis of periodontitis $[44,45]$.

\section{Mitsuokella dentalis}

Mitsuokella dentalis was named in honor of Mitsuoka, a Japanese bacteriologist and dentalis in Latin meaning "pertaining to teeth." The genus Mitsuokella was created based on morphological, biochemical, and chemotaxonomic criteria to include the species multacidus and dentalis [46].

Flynn et al. reported that M. dentalis is a constituent of the pathogenic microbiota in human periodontitis [47]. M. dentalis however does not have the ability to activate latent human fibroblast type, neutrophil interstitial procollagenases that lead to degradation of Type I collagen that is an essential step for periodontal tissue invasion and disease progression. Low proportions of $M$. dentalis comprising $2 \%$ of organisms isolated from periodontal pockets imply its minimal role as a periodontopathogenic bacterium. M. dentalis being a strict anaerobe is susceptible to metronidazole $[48,49]$.

\section{Treponema lecithinolyticum}

The term lecithinolyticum in Greek means "lekithos-egg yolk," "lytikos"-able to dissolve, for that reason lecithinolyticum produces effect similar to break down of egg yolk [50].

T. Lecithinolyticum was detected more frequently than T.denticola in periodontally diseased sites [51]. T. lecithinolyticum has been strongly associated with human periodontal diseases [52]. T. lecithinolyticum is being considered as a powerful periodontal pathogen due to the virulence potential of $T$. lecithinolyticum major surface proteins in inducing periodontitis and acute necrotizing ulcerative gingivitis.

Its major surface protein is composed of $\beta$ strands and loop regions [53]. These surface proteins play a pivotal role in cell adhesion and migration. They play a critical role in monocot adhesion and transendothelial migration responsible for initial infiltration of monocytes into periodontal tissues. T. lecithinolyticum induced the activation of MMP-2 in gingival fibroblasts and periodontal ligament cells [54, 55].

It also promotes osteoclastogenesis by production of PGE2 and 
osteoclast differentiation factor. T. lecithinolyticum can be considered a diagnostic marker due to its highest prevalence in generalized aggressive periodontitis, followed by chronic periodontitis, and least in periodontitis resistant group. T. lecithinolyticum is susceptible to metronidazole and nystatin $[56,57]$.

\section{Synergistes}

This bacterial division Synergistes comprises ubiquitous, diverse, and uncharacterized bacterial isolates. Numerous bacterial strains of Synergistes were isolated from human oral cavities [58, 59].

The Synergistes groups of organisms were retrieved by 16SrRNA sequences. Phylotypes have been isolated from sites with marginal periodontitis, endodontic infections, apical periodontitis, and dental caries. Fluorescent in situ hybridization was also used for Synergistes isolation from subgingival plaque [58-60].

Fretibacterium fastidiosum is an obligately anaerobic, motile, Gram-stain-negative, curved bacillus measuring 1-1.5 $\mathrm{mm}$ in width and ranging from $2-13 \mathrm{~mm}$ in length (mean $8 \mathrm{~mm}$ ), belonging to phylum Synergistetes. It was isolated form a deep periodontal pocket. This was described by Vartoukian SR et al in 2013 [61]. Fretibacterium sp. HOT 360 was seen to be present in higher levels in saliva of patients with periodontitis in a study by Khemwong et al in 2019 upon using qPCR with specific primers and Taqmanprobes. This species showed a significantly positive correlation with periodontal parameters such as probing pocket depth (PPD) and bleeding on probing (BOP). Thus, it was proposed that, their levels in saliva can be used as a potential biomarker for screening periodontitis [62].

Synergistes are most likely to be involved in periodontal pocket anaerobic environment. They are implicated mainly in anaerobic infections [63]. They produced microecological changes such as increased pocket depth, inflammation, anaerobiosis, and gingival tissue destruction [64]. Synergistes were higher in proportion in severe stages of periodontitis than in early stages of disease Synergistes [63].

\section{Anaeroglobus geminatus}

Anaeroglobus geminatus was first investigated in 2002. The prevalence of this organism was seen to be high in patients with chronic periodontitis and apical periodontitis correlating withlow bleeding on probing scores (indicative of gingival inflammation)and higher proportion of colonization ofsubgingival sites in chronic and aggressive periodontitis [65-68].

In a polymicrobial biofilm model, $A$. geminatus was found to cause quantitative proteomic shifts with particular effects on ribosomal proteins, proteolysis, carbon metabolic processes and iron transport. Collectively, these changes were seen to be related with increased virulence properties of the entire biofilm. This was studied using qPCR and label free proteomics [68].

\section{Desulfobulbus oralis}

Desulfobulbus oralis is the first human associated representative of its genus. It is a sulfate-reducing deltaproteobacterium which has adapted to the human oral subgingival niche by limiting its physiological range, losing some biosynthetic capabilities and metabolic independence, and by drastically reducing environmental detecting and signaling abilities [70].

Shi M et al, in 2018 using 16S rRNA gene high-throughput sequencing and bioinformatic analysis, found that the prevalence of Desulfobulbus sp. was more in aggressive forms of periodontitis however; it was negatively correlated with the probing depth [71]. In vitro studies have revealed elevated production of proinflammatory cytokines IL- $1 \beta$, IFN $-\alpha$, monocyte chemoattractant protein 1 (MCP-1), IL-6, IL-8, and IL-18 from human gingival keratinocytes exposed to this pathogen. This was seen in response to its surface associated proteins like leukotoxin and hemolysin. Cross et al, 2018 Further human clinical studies are required to understand the contribution of this species in periodontal pathogenesis [70].

\section{Methanobrevibacter oralis}

Methanobrevibacter oralis was first isolated from human subgingival plaque in 1994 [72].

The prevalence of archaea in subgingival plaque of periodontitis patients as compared to healthy subjects was revealed to be higher. They had a prevalence rate of $70.7 \%$ to $73.2 \%$. Upon PCR amplification of the archaea positive samples with known primers, most of them were found to be that of unculturable M. oralis [73].

Paul W Lepp et al in 2004, detected Archaeal small subunit (SSU) rDNA in $36 \%$ of periodontitis patients. Their archaeal SSU rDNA was detected in $76.6 \%$ of the periodontitis sites but undetected in the samples from periodontally healthy sites and tongue scrapings from periodontitis patients who were Archaea-positive. They saw a direct correlation between the relative profusion of archaeal SSU rDNA and the intensity of disease within the Archaea-positive subset of patients [74].

Their presence was also acknowledged to be at higher levels and proportions in aggressive forms of periodontitis in comparison with health [75]. A recent study has also claimed its assocication with peri implantitis. [76] However, their role, virulence and participation in periodontal breakdown exactly is unclear.

\section{Conclusion}

Thus, it is clear that, with developments in molecular technology and bacterial identification techniques, there is much more to add to the microbial front in the pathogenesis of periodontal disease. The focus should be on a polymicrobial etiology rather than only the Red complex bacteria as evidenced by this descriptive review. The periodontal microbiome as a whole needs to be evaluated and characterisd to better understand the roles of these novel bacteria in the initiation and progression of periodontal disease.

\section{References}

[1]. Paster BJ, Boches SK, Galvin JL, Ericson RE, Lau CN, Levanos VA, et al. Bacterial diversity in human subgingival plaque. J Bacteriol. 2001 Jun;183(12):3770-83.Pubmed PMID: 11371542.

[2]. Park OJ, Yi H, Jeon JH, Kang SS, Koo KT, Kum KY, et al. Pyrosequencing Analysis of SubgingivalMicrobiota in Distinct Periodontal Conditions. J Dent Res. 2015 Jul;94(7):921-7.Pubmed PMID: 25904141. 
[3]. Pérez-Chaparro PJ, Gonçalves C, Figueiredo LC, Faveri M, Lobão E, Tamashiro N, et al. Newly identified pathogens associated with periodontitis: a systematic review. J Dent Res. 2014 Sep;93(9):846-58.Pubmed PMID: 25074492 .

[4]. Socransky SS, Haffajee AD, Cugini MA, Smith C, Kent RL Jr. Microbial complexes in subgingival plaque. J ClinPeriodontol. 1998 Feb;25(2):13444.Pubmed PMID: 9495612

[5]. Hajishengallis G, Lamont RJ. Beyond the red complex and into more complexity: the polymicrobial synergy and dysbiosis (PSD) model of periodontal disease etiology. Mol Oral Microbiol. 2012 Dec;27(6):409-19.Pubmed PMID: 23134607

[6]. Nakazawa F, Poco SE, Ikeda T, Sato M, Kalfas S, Sundqvist G, et al. Cryptobacteriumcurtum gen. nov., sp. nov., a new genus of gram-positive anaerobic rod isolated from human oral cavities. Int J SystBacteriol. 1999 Jul;49 Pt 3:1193-200.Pubmed PMID: 10425779.

[7]. Kumar PS, Griffen AL, Barton JA, Paster BJ, Moeschberger ML, Leys EJ. New bacterial species associated with chronic periodontitis. J Dent Res. 2003 May;82(5):338-44.Pubmed PMID: 12709498

[8]. Lopez-Oliva I, Paropkari AD, Saraswat S, Serban S, Yonel Z, Sharma $\mathrm{P}$, et al. DysbioticSubgingival Microbial Communities in Periodontally Healthy Patients With Rheumatoid Arthritis. Arthritis Rheumatol. 2018 Jul;70(7):1008-1013.Pubmed PMID: 29513935.

[9]. Kim KS, Rowlinson MC, Bennion R, Liu C, Talan D, Summanen P, et al. Characterization of Slackiaexigua isolated from human wound infections, including abscesses of intestinal origin. J ClinMicrobiol. 2010 Apr;48(4):1070-5.Pubmed PMID: 20107092.

[10]. Wade WG, Downes J, Dymock D, Hiom SJ, Weightman AJ, Dewhirst FE, et al. The family Coriobacteriaceae: reclassification of Eubacteriumexiguum (Poco et al. 1996) and Peptostreptococcusheliotrinreducens (Lanigan 1976) as Slackiaexigua gen. nov., comb. nov.andSlackiaheliotrinireducens gen. nov., comb. nov., and Eubacteriumlentum (Prevot 1938) as Eggerthellalenta gen. nov., comb. nov.Int JSystBacteriol. 1999 Apr;49 (2):595-600.Pubmed PMID: 10319481

[11]. Poco SE Jr, Nakazawa F, Ikeda T, Sato M, Sato T, Hoshino E. Eubacteriumexiguum sp. nov., isolated from human oral lesions. Int J SystBacteriol. 1996 Oct;46(4):1120-4.Pubmed PMID: 8863445.

[12]. Smith AJ, Wade WG. Serum antibody response against oral Eubacterium species in periodontal disease. J Periodontal Res. 1999 Apr;34(3):175-8.Pubmed PMID: 10384406

[13]. Booth V, Downes J, Van den Berg J, Wade WG. Gram-positive anaerobic bacilli in human periodontal disease. J Periodontal Res. 2004 Aug;39(4):21320.Pubmed PMID: 15206913.

[14]. Tran T, Flynn MJ, Chen C, Slots J. Porphyromonasendodontalis in subgingival plaque. Clin Infect Dis. 1997 Sep;25Suppl 2:S222-3.Pubmed PMID: 9310685.

[15]. Lombardo Bedran TB, Marcantonio RA, Spin Neto R, Alves Mayer MP, Grenier D, Spolidorio LC, et al. Porphyromonasendodontalis in chronic periodontitis: a clinical and microbiological cross-sectional study. J Oral Microbiol. 2012;4.Pubmed PMID: 22232719

[16]. Downes J, Munson MA, Radford DR, Spratt DA, Wade WG. Shuttleworthiasatelles gen. nov., sp. nov., isolated from the human oral cavity. Int J SystEvolMicrobiol. 2002 Sep;52(5):1469-1475.Pubmed PMID: 12361248.

[17]. Colombo AP, Boches SK, Cotton SL, Goodson JM, Kent R, Haffajee AD, et al. Comparisons of subgingival microbial profiles of refractory periodontitis, severe periodontitis, and periodontal health using the human oral microbe identification microarray. J Periodontol. 2009 Sep;80(9):1421-32.Pubmed PMID: 19722792.

[18]. Hill GB, Ayers OM, Kohan AP. Characteristics and sites of infection of Eubacteriumnodatum, Eubacteriumtimidum, Eubacteriumbrachy, and other asaccharolytic eubacteria. J ClinMicrobiol. 1987 Aug;25(8):1540-5.Pubmed PMID: 3624445.

[19]. Booth V, Downes J, Van den Berg J, Wade WG. Gram-positive anaerobic bacilli in human periodontal disease. J Periodontal Res. 2004 Aug;39(4):21320.Pubmed PMID: 15206913.

[20]. Wade WG. The role of Eubacterium species in periodontal disease and other oral infections. Microb. Ecol. Health Dis. 1996 Jan 1;9(6):367-70.

[21]. Uematsu H, Hoshino E. Predominant obligate anaerobes in human periodontal pockets. J Periodontal Res. 1992 Jan;27(1):15-9.Pubmed PMID: 1531505 .

[22]. Kumar PS, Griffen AL, Moeschberger ML, Leys EJ. Identification of candidate periodontal pathogens and beneficial species by quantitative $16 \mathrm{~S}$ clonal analysis. J ClinMicrobiol. 2005 Aug;43(8):3944-55.Pubmed PMID: 16081935.

[23]. Cato EP, MOORE LV, Moore WE. Fusobacteriumalocis sp. nov.andFusobacterium sulci sp. nov.from the human gingival sulcus. Int J SystEvolMicrobiol. 1985 Oct 1;35(4):475-7.

[24]. Griffen AL, Beall CJ, Campbell JH, Firestone ND, Kumar PS, Yang ZK, et al. Distinct and complex bacterial profiles in human periodontitis and health revealed by $16 S$ pyrosequencing. ISME J. 2012 Jun;6(6):1176-85.Pubmed PMID: 22170420.

[25]. Aruni AW, Roy F, Fletcher HM. Filifactoralocis has virulence attributes that can enhance its persistence under oxidative stress conditions and mediate invasion of epithelial cells by porphyromonasgingivalis. Infect Immun. 2011 Oct;79(10):3872-86.Pubmed PMID: 21825062.

[26]. Aruni AW, Mishra A, Dou Y, Chioma O, Hamilton BN, Fletcher HM. Filifactoralocis--a new emerging periodontal pathogen. Microbes Infect. 2015 Jul;17(7):517-30.Pubmed PMID: 25841800.

[27]. Schlafer S, Riep B, Griffen AL, Petrich A, Hübner J, Berning M, et al. Filifactoralocis--involvement in periodontal biofilms. BMC Microbiol. 2010 Mar 1;10(1):66.Pubmed PMID: 20193074.

[28]. Wang Q, Jotwani R, Le J, Krauss JL, Potempa J, Coventry SC, et al. Filifactoralocis infection and inflammatory responses in the mouse subcutaneous chamber model. Infect Immun. 2014 Mar;82(3):1205-12.Pubmed PMID: 24379289.

[29]. Nokhbehsaim M, Nogueira AV, Damanaki A, Dalagiorgou G, Eick S, Adamopoulos C, et al. Regulation of matrix metalloproteinase-1 by Filifactor alocis in human gingival and monocytic cells. Clin Oral Investig. 2019 Aug 23:1-9.

[30]. Armstrong CL, Klaes CK, Vashishta A, Lamont RJ, Uriarte SM. Filifactoralocis manipulates human neutrophils affecting their ability to release neutrophil extracellular traps induced by PMA. Innate Immun. 2018 May;24(4):210-220.Pubmed PMID: 29649915.

[31]. Moffatt CE, Whitmore SE, Griffen AL, Leys EJ, Lamont RJ. Filifactoralocis interactions with gingival epithelial cells. Mol Oral Microbiol. 2011 Dec;26(6):365-73.Pubmed PMID: 22053964.

[32]. Aruni AW, Zhang K, Dou Y, Fletcher H. Proteome analysis of coinfection of epithelial cells with Filifactoralocis and Porphyromonasgingivalis shows modulation of pathogen and host regulatory pathways. Infect Immun. 2014 Aug;82(8):3261-74.Pubmed PMID: 24866790.

[33]. Aruni AW, Zhang K, Dou Y, Fletcher H. Proteome analysis of coinfection of epithelial cells with Filifactoralocis and Porphyromonasgingivalis shows modulation of pathogen and host regulatory pathways. Infect Immun. 2014 Aug;82(8):3261-74.Pubmed PMID: 24866790.

[34]. Olitsky PK, Gates FL. EXPERIMENTAL STUDIES OF THE NASOPHARYNGEAL SECRETIONS FROM INFLUENZA PATIENTS I. TRANSMISSION EXPERIMENTS WITH NASOPHARYNGEAL WASHINGS. J Exp Med. 1921 Jan 31;33(2):125-45.Pubmed PMID: 19868484.

[35]. Moore LV, Moore WE. Oribaculumcatoniae gen. nov., sp. nov.; Catonellamorbi gen. nov., sp. nov.; Hallellaseregens gen. nov., sp. nov.; Johnsonellaignava gen. nov., sp. nov.; and Dialisterpneumosintes gen. nov., comb. nov., nom. rev., Anaerobic gram-negative bacilli from the human gingival crevice. Int J SystBacteriol. 1994 Apr;44(2):187-92.Pubmed PMID: 8186083.

[36]. Jumas-Bilak E, Jean-Pierre H, Carlier JP, Teyssier C, Bernard K, Gay B, et al. Dialistermicraerophilus sp. nov.andDialisterpropionicifaciens sp. nov., isolated from human clinical samples. Int J SystEvolMicrobiol. $2005 \mathrm{Nov} ; 55$ (Pt 6):2471-2478.Pubmed PMID: 16280512.

[37]. Doan N, Contreras A, Flynn J, Slots J, Chen C. Molecular identification of Dialisterpneumosintes in subgingival plaque of humans. J ClinMicrobiol. 2000 Aug;38(8):3043-7.Pubmed PMID: 10921975

[38]. Colombo AP, Boches SK, Cotton SL, Goodson JM, Kent R, Haffajee AD, et al. Comparisons of subgingival microbial profiles of refractory periodontitis, severe periodontitis, and periodontal health using the human oral microbe identification microarray. J Periodontol. 2009 Sep;80(9):1421-32.Pubmed PMID: 19722792

[39]. Silva-Boghossian CM, Neves AB, Resende FA, Colombo AP. Suppurationassociated bacteria in patients with chronic and aggressive periodontitis. J Periodontol. 2013 Sep;84(9):e9-e16.Pubmed PMID: 23327648.

[40]. Kamma JJ, Contreras A, Slots J. Herpes viruses and periodontopathic bacteria in early-onset periodontitis. J ClinPeriodontol. 2001 Sep;28(9):879-85. Pubmed PMID: 11493359.

[41]. Ferraro CT, Gornic C, Barbosa AS, Peixoto RJ, Colombo AP. Detection of Dialisterpneumosintes in the subgingival biofilm of subjects with periodontal disease. Anaerobe. 2007 Oct-Dec;13(5-6):244-8.Pubmed PMID: 17980633.

[42]. Moore LV, Johnson JL, Moore WE. Selenomonasnoxia sp. nov., Selenomonasflueggei sp. nov., Selenomonasinfelix sp. nov., Selenomonasdianae sp. nov., and Selenomonasartemidis sp. nov., from the human gingival crevice. Int J SystEvolMicrobiol . 1987 Jul 1;37(3):271-80.

[43]. Maiden MF, Tanner A, Moore WE. Identification of Selenomonas species by whole-genomic DNA probes, sodium dodecyl sulfate-polyacrylamide gel electrophoresis, biochemical tests and cellular fatty acid analysis. Oral MicrobiolImmunol. 1992 Feb;7(1):7-13.Pubmed PMID: 1528628.

[44]. Hofstad T, Naess V, Skaug N. Biological activity of lipopolysaccharides from 
oral Selenomonas. Scand J Dent Res. 1986 Dec;94(6):515-20.Pubmed PMID: 3468599.

[45]. Deng K, Ouyang XY, Chu Y, Zhang Q. SubgingivalMicrobiome of Gingivitis in Chinese Undergraduates. Chin J Dent Res. 2017;20(3):145-152. Pubmed PMID: 28808698.

[46]. Haapasalo M, Ranta H, Shah H, Ranta K, Lounatmaa K, Kroppenstedt RM. Mitsuokelladentalis sp. nov.from dental root canals. Int J SystEvolMicrobiol. 1986 Oct 1:36(4):566-8.

[47]. Flynn MJ, Li G, Slots J. Mitsuokelladentalis in human periodontitis. Oral MicrobiolImmunol. 1994 Aug;9(4):248-50.Pubmed PMID: 7478766.

[48]. Haapasalo M, Ranta H, Shah H, Ranta K, Lounatmaa K, Kroppenstedt RM. Biochemical and structural characterization of an unusual group of gram-negative, anaerobic rods from human periapicalosteitis. J Gen Microbiol. 1986 Feb;132(2):417-26.Pubmed PMID: 2872267.

[49]. Shah HN, Collins DM. Prevotella, a new genus to include Bacteroidesmelaninogenicus and related species formerly classified in the genus Bacteroides. Int J SystBacteriol. 1990 Apr;40(2):205-8.Pubmed PMID: 2223612.

[50]. Choi BK, Paster BJ, Dewhirst FE, Göbel UB. Diversity of cultivable and uncultivable oral spirochetes from a patient with severe destructive periodontitis. Infect Immun. 1994 May;62(5):1889-95.Pubmed PMID: 8168954.

[51]. Moter A, Hoenig C, Choi BK, Riep B, Göbel UB. Molecular epidemiology of oral treponemes associated with periodontal disease. J ClinMicrobiol. 1998 May;36(5):1399-403.Pubmed PMID: 9574713.

[52]. Park KK, Heuner K, Göbel UB, Yoo YJ, Kim CK, Choi BK. Cloning and characterization of a major surface protein (MspTL) of Treponemalecithinolyticum associated with rapidly progressive periodontitis. FEMS MicrobiolLett. 2002 Feb 5;207(2):185-92.Pubmed PMID: 11958938.

[53]. Jun HK, Lee HR, Lee SH, Choi BK. Mapping of the proinflammatory domains of MspTL of Treponemalecithinolyticum. Microbiology (Reading). 2007 Aug;153(8):2386-2392.Pubmed PMID: 17660403.

[54]. Choi BK, Jung JH, Suh HY, Yoo YJ, Cho KS, Chai JK, et al. Activation of matrix metalloproteinase-2 by a novel oral spirochetal species Treponemalecithinolyticum. J Periodontol. 2001 Nov;72(11):1594-600.Pubmed PMID: 11759872 .

[55]. Lee SH, Kim KK, Choi BK. Upregulation of intercellular adhesion molecule 1 and proinflammatory cytokines by the major surface proteins of Treponemamaltophilum and Treponemalecithinolyticum, the phylogenetic group IV oral spirochetes associated with periodontitis and endodontic infections. Infect Immun. 2005 Jan;73(1):268-76.Pubmed PMID: 15618163.

[56]. Edwards AM, Jenkinson HF, Woodward MJ, Dymock D. Binding properties and adhesion-mediating regions of the major sheath protein of Treponemadenticola ATCC 35405. Infect Immun. 2005 May;73(5):2891-8.Pubmed PMID: 15845495.

[57]. Lee SH, Kim KK, Choi BK. Upregulation of intercellular adhesion molecule 1 and proinflammatory cytokines by the major surface proteins of Treponemamaltophilum and Treponemalecithinolyticum, the phylogenetic group IV oral spirochetes associated with periodontitis and endodontic infections. Infect Immun. 2005 Jan;73(1):268-76.Pubmed PMID: 15618163.

[58]. Vartoukian SR, Palmer RM, Wade WG. Diversity and morphology of members of the phylum "synergistetes" in periodontal health and disease. Appl Environ Microbiol. 2009 Jun;75(11):3777-86.Pubmed PMID: 19346352.

[59]. Siqueira JF Jr, Rôças IN. Molecular detection and identification of Synergistesphylotypes in primary endodontic infections. Oral Dis. 2007 Jul;13(4):398-401.Pubmed PMID: 17577326.

[60]. Hugenholtz P, Goebel BM, Pace NR. Impact of culture-independent studies on the emerging phylogenetic view of bacterial diversity. J Bacteriol. 1998 Sep;180(18):4765-74.Pubmed PMID: 9733676
[61]. Vartoukian SR, Downes J, Palmer RM, Wade WG. Fretibacteriumfastidiosum gen. nov., sp. nov., isolated from the human oral cavity. Int J SystEvolMicrobiol. 2013 Feb;63(Pt 2):458-463.Pubmed PMID: 22493171.

[62]. Khemwong T, Kobayashi H, Ikeda Y, Matsuura T, Sudo T, Kano C, et al. Fretibacterium sp. human oral taxon 360 is a novel biomarker for periodontitis screening in the Japanese population. PLoS One. 2019 Jun 19;14(6):e0218266.Pubmed PMID: 31216300.

[63]. Belibasakis GN, Oztürk VÖ, Emingil G, Bostanci N. Synergistetes cluster A in saliva is associated with periodontitis. J Periodontal Res. 2013 Dec;48(6):727-32.Pubmed PMID: 23441995.

[64]. You M, Mo S, Watt RM, Leung WK. Prevalence and diversity of Synergistetes taxa in periodontal health and disease. J Periodontal Res. 2013 Apr;48(2):159-68.Pubmed PMID: 22881378.

[65]. Scher JU, Ubeda C, Equinda M, Khanin R, Buischi Y, Viale A, et al. Periodontal disease and the oral microbiota in new-onset rheumatoid arthritis. Arthritis Rheum. 2012 Oct;64(10):3083-94.Pubmed PMID: 22576262.

[66]. Chugal N, Wang JK, Wang R, He X, Kang M, Li J, et al. Molecular characterization of the microbial flora residing at the apical portion of infected root canals of human teeth. J Endod. 2011 Oct;37(10):1359-64.Pubmed PMID: 21924182

[67]. Camelo-Castillo A, Novoa L, Balsa-Castro C, Blanco J, Mira A, Tomás I. Relationship between periodontitis-associated subgingivalmicrobiota and clinical inflammation by 16S pyrosequencing. J ClinPeriodontol. 2015 Dec;42(12):1074-82.Pubmed PMID: 26461079.

[68]. Bao K, Papadimitropoulos A, Akgül B, Belibasakis GN, Bostanci N. Establishment of an oral infection model resembling the periodontal pocket in a perfusion bioreactor system. Virulence. 2015;6(3):265-73.Pubmed PMID: 25587671.

[69]. Bao K, Bostanci N, Thurnheer T, Belibasakis GN. Proteomic shifts in multispecies oral biofilms caused by Anaeroglobusgeminatus. Sci Rep. 2017 Jun 30;7(1):4409.Pubmed PMID: 28667274.

[70]. Cross KL, Chirania P, Xiong W, Beall CJ, Elkins JG, Giannone RJ, et al. Insights into the Evolution of Host Association through the Isolation and Characterization of a Novel Human Periodontal Pathobiont, Desulfobulbusoralis. mBio. 2018 Mar 13;9(2):e02061-17.Pubmed PMID: 29535201.

[71]. 71.Shi M, Wei Y, Hu W, Nie Y, Wu X, Lu R. The SubgingivalMicrobiome of Periodontal Pockets With Different Probing Depths in Chronic and Aggressive Periodontitis: A Pilot Study. Front Cell Infect Microbiol. 2018 May 1;8:124.Pubmed PMID: 29765908.

[72]. Ferrari A, Brusa T, Rutili A, Canzi E, Biavati B. Isolation and characterization of Methanobrevibacteroralis sp. nov.Curr. Microbiol. 1994 Jul;29(1):712.

[73]. Li CL, Liu DL, Jiang YT, Zhou YB, Zhang MZ, Jiang W, et al. Prevalence and molecular diversity of Archaea in subgingival pockets of periodontitis patients. Oral MicrobiolImmunol. 2009 Aug;24(4):343-6.Pubmed PMID: 19572899.

[74]. Lepp PW, Brinig MM, Ouverney CC, Palm K, Armitage GC, Relman DA. MethanogenicArchaea and human periodontal disease. ProcNatlAcadSci U S A. 2004 Apr 20;101(16):6176-81.Pubmed PMID: 15067114.

[75]. Matarazzo F, Ribeiro AC, Feres M, Faveri M, Mayer MP. Diversity and quantitative analysis of Archaea in aggressive periodontitis and periodontally healthy subjects. J ClinPeriodontol. 2011 Jul;38(7):621-7.Pubmed PMID: 21539593.

[76]. Belkacemi S, Mazel A, Tardivo D, Tavitian P, Stephan G, Bianca G, et al. Peri-implantitis-associated methanogens: a preliminary report. Sci Rep. 2018 Jun 21:8(1):9447.Pubmed PMID: 29930395. 